\title{
ANALISIS DAMPAK POLA HIDUP TERHADAP KEBUGARAN PADA SISWA KELAS XI IPS 1 SMA NEGERI 8 KOTA BENGKULU
}

\author{
Septika Usde Vita Sam \\ PENJAS FKIP UNIB, e-mail: septikausde@gmail.com
}

\author{
Sugiyanto \\ Universitas Bengkulu \\ Defliyanto \\ Universitas Bengkulu
}

\begin{abstract}
Abstrak
Penelitian ini bertujuan untuk mengetahui dampak pola hidup terhadap kebugaran siswa XI IPS 1 SMA Negeri 8 Kota Bengkulu. Jenis penelitian ini adalah deskriptif kualitatif. Populasi dan sampel yang digunakan dalam penelitian ini adalah seluruh siswa kelas XI IPS 1 SMA Negeri 8 Kota Bengkulu yang berjumlah 35 orang. Instrumen yang digunakan angket tertutup dan tes lari 2.400 meter. Teknik pengumpulan data penelitian menggunakan angket dan tes. Teknik analisis data menggunakan teknik analisis data triangulasi dan statistic deskriptif (tabulasi frekuensi). Berdasarkan hasil penelitian hasil data diproleh sehingga dibagi menjadi 2 keriteria yaitu 22 laki-laki dan 13 perempuan ternyata rata-rata kecakapan dalam dampak pola hidup terhadap kebugaran jasmani pada siswa kelas XI IPS 1 SMA Negeri 8 Kota Bengkulu untuk lakilaki dikategorikan kurang atau 12,29\%, sedangkan perempuan sebagian besar berkategori sedang atau 16,38\%. Adapun hasil angket dapat ditarik simpulan dari jawaban responden Siswa XI IPS 1 SMA Negeri 8 Kota Bengkulu memiliki kesehatan dan kebugaran yang belum terpenuhi. Pola hidup siswa belum banyak mendapat pemahaman tentang pembelajaran pola hidup dan kebugaran yang benar.
\end{abstract}

Kata kunci: Pola Hidup, Kebugaran

\begin{abstract}
This study aims to determine the impact of lifestyle on student fitness XI IPS 1 SMA Negeri 8 Kota Bengkulu. The type of this research is descriptive qualitative. Population and samples used in this research are all students of class XI IPS 1 SMA Negeri 8 Kota Bengkulu which amounted to 35 people. The instrument used was a closed questionnaire and a 2,400 meter test run. Techniques of collecting research data using questionnaires and tests. Data analysis technique used data analysis technique triangulation and descriptive statistic (frequency tabulation). Based on the results of research results diproleh so divided into 2 keriteria that is 22 men and 13 women turns out the average skills in the impact of lifestyle on physical fitness in students of class XI IPS 1 SMA Negeri 8 Kota Bengkulu for men categorized less or 12 , 29\%, while women mostly categorized as being or $16.38 \%$. The questionnaire results can be drawn conclusion from the respondent's answer Student XI IPS 1 SMA Negeri 8 Kota Bengkulu have health and fitness that has not been fulfilled. The pattern of life of the students has not got much understanding of the correct lifestyle and fitness learning.
\end{abstract}

Keywords: lifestyle, fitness 


\section{PENDAHULUAN}

Indonesia sebagai salah satu negara berkembang masih berjuang menghadapi berbagai masalah kesehatan. Kesehatan merupakan investasi untuk mendukung pembangunan bangsa. Pembangunan kesehatan harus dipandang sebagai perioritas utama untuk meningkatkan kualitas sumber daya manusia. Upaya peningkatan kualitas sumber daya manusia tersebut dapat dimulai dari menerapkan pola hidup yang akan membawa dampak positif bagi kesehatan tubuh manusia.

Pola hidup adalah bagian dari kebutuhan sekunder manusia yang bisa berubah bergantung zaman atau keinginan seseorang untuk mengubah gaya hidupnya. Gaya hidup bisa dilihat dari cara berpakaian, kebiasaan, dan lainlain. Pola hidup yang terpogram dapat membantu setiap individu dalam melaksanakan aktivitas sehari-hari disesuaikan dengan umur dan kondisi dimana kita berada. Apabila pola hidup dilaksanakan dengan baik dan benar tentunya akan sangat mendukung pencapaian produktivitas kerja yang tinggi, dimana pada akhirnya juga akan meningkatkan budaya disiplin, sebab tanpa disiplin yang baik maka pola hidup hasilnya akan sulit dicapai secara optimal, akan tetapi sebaliknya bagi orang yang melakukannya dengan disiplin yang tinggi tentunya akan membuahkan hasil seperti yang diharapkan yaitu tubuh akan tetap sehat

Pola hidup pada dasarnya merupakan program yang menyeluruh mengenai kesehatan, kebugaran jasmani, gizi dan rekreasi sebagai upaya menyeimbangkan antara aktivitas fisik dan mental, seperti aktivitas olahraga yang dilaksanakan secara terencana tidak hanya akan membentuk fisik, intelektual ,moral, semangat kerja dan dedikasi secara individu, melainkan juga akan memperbaiki kualitas kehidupan pelakunya sebagai anggota kelompok yang ada dalam masyarakat. Selain itu, nilai-nilai yang terkandung dalam olahraga juga mempunyai kontribusi bermakna terhadap pembangunan watak, semangat juang dan prestasi yang tinggi, sehingga dapat dijadikan modal berharga dalam rangka persaingan dengan bangsa lain di forum internasional menurut Suharto, dkk (2003:1). Kebugaran jasmani adalah kemampuan seseorang dalam melakukan aktivitas keseharian tanpa mengalami kelelahan yang berarti dan masih mempunyai cadangan sisa tenaga untuk melakukan aktivitas yang lain. Kebugaran ada hubugannya dengan kesehatan karena kesehatan merupakan suatu keadaan sehat baik secara fisik, mental, maupun sosial. Saat ini kebugaran jasmani yang terlihat dalam peserta didik kurang mendapatkan penanganan khusus yang hanya fokus memperhatikan kualitas fisik yang bugar. Kebanyakan dari pendidik atau guru pendidikan jasmani hanya memusatkan pada materi tanpa adanya perlakuan. Padahal kebugaran jasmani merupakan aspek pendukung untuk tercapainya pola hidup sehat yang maksimal.

Berdasarkan observasi awal pada tanggal 24 januari 2017 yang peneliti lakukan di SMA Negeri 8 Kota Bengkulu bahwa pengetahuan siswa masih kurang dalam penerapan pola hidup, hal ini terlihat dari sebagian dari siswa yang masih banyak terlambat datang ke sekolah, akibat dari pola tidur yang tidak teratur, dari segi berpakaian bisa dilihat dari kurang rapinya baju siswa dan 
kebersihan dari baju siswa. Kemudian dapat dilihat juga dari kegiatan siswa saat di sekolah ketika istirahat, ada sebagian siswa yang waktu istirahatnya untuk membaca di perpustakan, sementara siswa yang lain ada yang pergi ke kantin, ada yang bermain basket di lapangan dan ada juga yang hanya berdiam diri di kelas. Dengan demikian dapat disimpulkan bahwa siswa yang hanya berdiam diri di kelas tersebut merupakan contoh siswa yang kurang aktif melakukan aktivitas gerak sehingga menyebabkan tubunya tidak bugar, sedangkan siswa yang melakukan aktivitas gerak atau kegiatan yang lainnya diluar kelas seperti bermain di lapangan itu merupakan contoh siswa yang memiliki pola hidup sehat.

Demikian kebugaran jasmani sangat diperlukan dalam menunjang keberhasilan dalam belajar siswa. Salah satu faktor yang mempengaruhi siswa tidak masuk sekolah dikarenakan sakit. kurangnya kebugaran dapat menyebabkan siswa kurang fokus, rendahnya kemampuan penalaran, pemahaman, dan mengemukakan pendapat yang baik saat kegiatan pembelajaran.

\section{METODE}

Berdasarkan permasalahan yang akan dibahas dalam penelitian ini, maka jenis penelitian ini berbentuk penelitian kualitatif dengan metode deskriptif, yaitu penelitian yang bertujuan untuk melihat suatu apa adanya. Seperti yang dikemukakan oleh Mahmud (2011:100) bahwa: "Penelitian deskriptif adalah suatu penelitian yang diupayakan untuk mengamati permasalahan secara sistematis dan akurat mengenai fakta".. Tempat penelitian dilakukan di
Kota Bengkulu, dengan menggunakan stadion Universitas Bengkulu untuk pelaksanaan tes keugaran jasmani.. Penelitian dilakukan pada semester genap tahun ajaran 2016/2017. . Maka dari itu peneliti membuat populasi dan sampel dalam penelitian ini adalah seluruh siswa-siswi kelas XI IPS 1 SMA Negeri 8 Kota Bengkulu yang berjumlah 35 orang. Menurut Sugiyono (2012:142) angket merupakan teknik pengumpulan data di mana partisipan/responden mengisi pertanyaan kemudian setelah diisi dengan lengkap mengembalikan kepada peneliti. Dalam peneltian ini menggunakan angket tertutup. Angket tertutup adalah pertanyaan yang telah disediakan peneliti dan mengharapkan responden menjawab dengan singkat dan memilih salah satu jawaban dari setiap pertanyaan yang telah tersedia, sehingga responden bebas memilih jawaban sesuai dengan karakteristiknya masing-masing. Menurut asril (2010:4) test adalah salah satu alat atau prosedur yang diperlukan untuk mengumpulkan data seseorang, benda atau objek tertentu melalui pengukuran dan aturan-aturan tertentu. Dalam penelitian ini tes yang digunakan ialah tes aerobic lari 2.400 meter (Metode Cooper).

1. Angket

Jenis angket yang digunakan adalah angket tertutup, dimana peneliti menyiapkan kisi-kisi pertanyaan sesuai dengan rumusan masalah diatas. Setelah itu peneliti meminta kesediaan responden untuk mengisi angket yang telah dibuat kemudian angket dibagikan, selanjutnya angket yang telah diisi 
dikumpulkan kembali untuk diolah data selanjutnya dengan analisis data.

2. Tes aerobic lari 2.400 meter (metode Cooper)

Tes lari 2.400 meter yang bertujuan untuk mengukur kemampuan dan kesanggupan kerja fisik Seseorang .Teknik analisis data yang digunakan untuk menguji data yang telah diperoleh menggunakan teknik analisis data triangulasi dan statistik dekriptif (tabulasi frekuensi). Triangulasi diartikan sebagai teknik pengumpulan data yang bersifat menggabungkan dari berbagai teknik pengumpulan data dan sumber data yang telah ada. statistik deskriptif (tabulasi frekuensi) dengan cara mendeskripsikan hasil pengamatan yang diperoleh dari dari pengukuran (tes) terhadap pola hidup dan kebugaran jasmani. Setelah terkumpul maka langka selanjutnya menganalisis data-data tersebut agar bisa menarik kesimpulan menggunakan teknik analisis data dengan rumus persentase

$$
\left(\mathrm{p}=\frac{f}{n} x 100 \% .\right) .
$$

\section{HASIL DAN PEMBAHASAN}

\section{Hasil}

Berdasarkan hasil dari angket tentang dampak pola hidup terhadap kebugaran jasmani pada item pertanyaan no 1 responden yang mejawab (e) rajin berolahraga pagi hari = 15 siswa, yang menjawab (d) rajin berolahraga sore hari $=14$ siswa, yang menjawab (c) rajin berolahraga siang hari $=6$ siswa, sedangkan yang menjawab (b) rajin berolahraga pagi hari dan malam hari, dan (a) rajin berolahraga malam hari adalah tidak ada. (didapat dari hasil penjumlahan jawaban a,b,c,d, dan e) maka hasil presentase yang menjawab (e) adalah $p=$ $\frac{15}{35} \times 100 \%=42,86 \%, \quad$ hasil presentase yang menjawab (d) adalah $p=\frac{14}{35} \times 100 \%=40 \%$, hasil presentase yang menjawab (c) $p=$ $\frac{6}{35} \times 100 \%=17,14 \%$, sedangkan yang menjawab (b) dan (a) adalah $0 \%$.

Berdasarkan hasil dari angket tentang dampak pola hidup terhadap kebugaran jasmani pada item pertanyaan no 2 responden yang mejawab (e) selalu = 20 siswa, yang menjawab (d) sering= 6 siswa atau siswi, yang menjawab (c) kadangkadang = 5 siswa, sedangkan yang menjawab (b) jarang sekali = 4 siswa, dan (a) tidak pernah adalah tidak ada. (didapat dari hasil penjumlahan jawaban a,b,c,d, dan e) maka hasil presentase yang menjawab (e) adalah $p=\frac{20}{35} \times 100 \%=57,14 \%$, hasil presentase yang menjawab (d) adalah $p=\frac{6}{35} \times 100 \%=17,14 \%$, hasil presentase yang menjawab (c) $p=\frac{5}{35} \times 100 \%=14,29 \%, \quad$ hasil presentase yang menjawab (b) $p=$ $\frac{4}{35} \times 100 \%=11,43 \% \quad$ sedangkan yang menjawab (a) adalah $0 \%$.

Berdasarkan hasil dari angket tentang dampak pola hidup terhadap kebugaran jasmani pada item pertanyaan no 3 responden yang mejawab (e) selalu = 24 siswa, yang menjawab (d) sering= 8 siswa, yang menjawab (c) kadang-kadang $=3$ 
siswa, sedangkan yang menjawab (b) jarang sekali, dan (a) tidak pernah adalah tidak ada. (didapat dari hasil penjumlahan jawaban a,b,c,d, dan e) maka hasil presentase yang menjawab (e) adalah $p=$ $\frac{24}{35} \times 100 \%=68,57 \%, \quad$ hasil presentase yang menjawab (d) adalah $\quad p=\frac{8}{35} \times 100 \%=22,86 \%$, hasil presentase yang menjawab (c) $p=\frac{3}{35} x 100 \%=8,57 \%$, sedangkan yang menjawab (b) dan (a) adalah $0 \%$.

Berdasarkan hasil dari angket tentang dampak pola hidup terhadap kebugaran jasmani pada item pertanyaan no 4 responden yang mejawab (e) selalu = 10 siswa, yang menjawab (d) sering = 6 siswa, yang menjawab (c) kadang-kadang $=15$ siswa, sedangkan yang menjawab (b) jarang sekali tidak ada, dan yang menjawab (a) tidak pernah = 4 siswa. (didapat dari hasil penjumlahan jawaban a,b,c,d, dan e) maka hasil presentase yang menjawab (e) adalah $p=\frac{10}{35} \times 100 \%=28,57 \%$, hasil presentase yang menjawab (d) adalah $\quad p=\frac{6}{35} \times 100 \%=17,14 \%$, hasil presentase yang menjawab (c) $p=\frac{15}{35} \times 100 \%=42,86 \%, \quad$ hasil presentase yang menjawab (b) adalah $0 \%$ sedangkan yang menjawab (a) adalah $p=$ $\frac{4}{35} \times 100 \%=11,43 \%$.

Berdasarkan hasil dari angket tentang dampak pola hidup terhadap kebugaran jasmani pada item pertanyaan no 5 responden yang mejawab (e) selalu = 10 siswa, yang menjawab (d) sering = 20 siswa, yang menjawab (c) kadang-kadang $=5$ siswa, sedangkan yang menjawab (b) jarang sekali, dan (a) tidak pernah adalah tidak ada. (didapat dari hasil penjumlahan jawaban a,b,c,d, dan e) maka hasil presentase yang menjawab (e) adalah $p=$ $\frac{10}{35} \times 100 \%=28,57 \%$, hasil presentase yang menjawab (d) adalah $\quad p=\frac{20}{35} \times 100 \%=57,14 \%$, hasil presentase yang menjawab (c) $p=\frac{5}{35} x 100 \%=14,29 \%$, sedangkan yang menjawab (b) dan (a) adalah $0 \%$.

Berdasarkan hasil dari angket tentang dampak pola hidup terhadap kebugaran jasmani pada item pertanyaan no 6 responden yang mejawab (e) selalu = 5 siswa, yang menjawab $(d)$ sering = 15 siswa, yang menjawab (c) kadang-kadang $=3$ siswa, sedangkan yang menjawab (b) jarang sekali = 10 siswa, dan yang menjawab (a) tidak pernah = 2 siswa. (didapat dari hasil penjumlahan jawaban a,b,c,d, dan e) maka hasil presentase yang menjawab (e) adalah $\quad p=\frac{5}{35} \times 100 \%=14,29 \%$, hasil presentase yang menjawab (d) adalah $p=\frac{15}{35} \times 100 \%=42,86 \%$, hasil presentase yang menjawab (c) $p=\frac{3}{35} \times 100 \%=8,57 \%, \quad$ hasil presentase yang menjawab (b) $p=$ $\frac{10}{35} \times 100 \%=28,57 \%$, sedangkan yang menjawab (a) adalah $p=$ $\frac{2}{35} \times 100 \%=5,71 \%$.

Berdasarkan hasil dari angket tentang dampak pola hidup terhadap 
kebugaran jasmani pada item pertanyaan no 7 responden yang mejawab (e) 7-8 jam sehari = 5 siswa, yang menjawab (d) 5-6 jam sehari = 10 siswa, yang menjawab (c) 4-5 jam sehari = 15 siswa, sedangkan yang menjawab (b) 3-4 jam sehari $=5$ siswa, dan yang menjawab (a) 2-3 jam sehari adalah tidak ada . (didapat dari hasil penjumlahan jawaban $a, b, c, d$, dan e) maka hasil presentase yang menjawab (e) adalah $p=$ $\frac{5}{35} \times 100 \%=14,29 \%, \quad$ hasil presentase yang menjawab (d) adalah $p=\frac{10}{35} \times 100 \%=28,57 \%$, hasil presentase yang menjawab (c) $p=\frac{15}{35} \times 100 \%=42,86 \%$, hasil presentase yang menjawab (b) $p=$ $\frac{5}{35} \times 100 \%=14,29 \%$, sedangkan yang menjawab (a) adalah $0 \%$.

Berdasarkan hasil dari angket tentang dampak pola hidup terhadap kebugaran jasmani pada item pertanyaan no 8 responden yang mejawab (e) tidak pernah adalah tidak ada, yang menjawab (d) jarang sekali = 5 siswa, yang menjawab (c) kadang-kadang = 10 siswa, sedangkan yang menjawab (b) sering = 20 siswa, dan yang menjawab (a) selalu adalah tidak ada. (didapat dari hasil penjumlahan jawaban $a, b, c, d$, dan e) maka hasil presentase yang menjawab (e) adalah $0 \%$ hasil presentase yang menjawab (d) adalah $\quad p=\frac{5}{35} \times 100 \%=14,29 \%$, hasil presentase yang menjawab (c) $p=\frac{10}{35} \times 100 \%=28,57 \%, \quad$ hasil presentase yang menjawab (b) $p=$ $\frac{20}{35} \times 100 \%=57,14 \%, \quad$ sedangkan yang menjawab (a) adalah $0 \%$.

Berdasarkan hasil dari angket tentang dampak pola hidup terhadap kebugaran jasmani pada item pertanyaan no 9 responden yang mejawab (e) tidak pernah adalah tidak ada, yang menjawab (d) jarang sekali adalah tidak ada (c) kadangkadang = 5 siswa, sedangkan yang menjawab (b) sering = 10 siswa, dan yang menjawab (a) selalu $=20$ siswa. (didapat dari hasil penjumlahan jawaban a,b,c,d, dan e) maka hasil presentase yang menjawab (e) adalah $0 \%$ hasil presentase yang menjawab (d) adalah 0\%, hasil presentase yang menjawab (c) $p=$ $\frac{5}{35} \times 100 \%=14,29 \%, \quad$ hasil presentase yang menjawab (b) $p=$ $\frac{10}{35} \times 100 \%=28,57 \%$, sedangkan hasil persentase yang menjawab (a) $p=\frac{20}{35} x 100 \%=57,14 \%$.

Berdasarkan hasil dari angket tentang dampak pola hidup terhadap kebugaran jasmani pada item pertanyaan no 10 responden yang mejawab (e) sangat berpengaruh = 20 siswa, yang menjawab (d) berpengaruh = 10 siswa, yang menjawab (c) biasa saja $=5$ siswa, sedangkan yang menjawab (b) tidak berpengaruh, dan (a) sangat tidak berpengaruh adalah tidak ada. (didapat dari hasil penjumlahan jawaban a,b,c,d, dan e) maka hasil presentase yang menjawab (e) adalah $\quad p=\frac{20}{35} \times 100 \%=57,14 \%$, hasil presentase yang menjawab (d) adalah $p=\frac{10}{35} \times 100 \%=28,57 \%$, 
hasil presentase yang menjawab (c) $p=\frac{5}{35} x 100 \%=14,29 \%$, sedangkan yang menjawab (b) dan (a) adalah $0 \%$.

Berdasarkan hasil dari angket tentang dampak pola hidup terhadap kebugaran jasmani pada item pertanyaan no 11 responden yang mejawab (e) kekuatan otot, kelenturan, daya tahan dan kelincahan $=20$ siswa, yang menjawab (d) koordinasi, komposisi tubuh, kecepatan reaksi dan kekuatan = 10 siswa, yang menjawab (c) kelincahan dan keseimbangan $=5$ siswa, sedangkan yang menjawab (b) kekuatan otot, kelenturan, dan (a) cukup daya tahan otot adalah tidak ada. (didapat dari hasil penjumlahan jawaban a,b,c,d, dan e) maka hasil presentase yang menjawab (e) adalah $p=\frac{20}{35} \times 100 \%=57,14 \%$, hasil presentase yang menjawab $(d)$ adalah $p=\frac{10}{35} \times 100 \%=28,57 \%$, hasil presentase yang menjawab (c) $p=\frac{5}{35} \times 100 \%=14,29 \%$, sedangkan yang menjawab (b) dan (a) adalah $0 \%$.

Berdasarkan hasil dari angket tentang dampak pola hidup terhadap kebugaran jasmani pada item pertanyaan no 12 responden yang mejawab (e) selalu adalah tidak ada, yang menjawab (d) sering $=5$ siswa, yang menjawab (c) jarang sekali $=20$ siswa, sedangkan yang menjawab (b) tidak pernah = 10 siswa, dan yang menjawab (a) sangat tidak pernah adalah tidak ada. (didapat dari hasil penjumlahan jawaban a,b,c,d, dan e) maka hasil presentase yang menjawab (e) adalah $0 \%$ hasil presentase yang menjawab (d) adalah $\quad p=\frac{5}{35} \times 100 \%=14,29 \%$, hasil presentase yang menjawab (c) $p=\frac{20}{35} \times 100 \%=57,14 \%, \quad$ hasil presentase yang menjawab (b) $p=$ $\frac{10}{35} \times 100 \%=28,57 \%$, sedangkan yang menjawab (a) adalah $0 \%$.

Berdasarkan hasil dari angket tentang dampak pola hidup terhadap kebugaran jasmani pada item pertanyaan no 13 responden yang mejawab (e) sudah banyak mengetahui $=3$ siswa, yang menjawab (d) cukup = 8 siswa, yang menjawab (c) hanya sedikit $=22$ siswa, sedangkan yang menjawab (b) tidak mengetahui $=2$ sisw, dan yang menjawab (a) sangat tidak mengetahui adalah tidak ada. (didapat dari hasil penjumlahan jawaban a,b,c,d, dan e) maka hasil presentase yang menjawab (e) adalah $\quad p=\frac{3}{35} \times 100 \%=8,57 \%$ hasil presentase yang menjawab (d) adalah $\quad p=\frac{8}{35} \times 100 \%=22,86 \%$, hasil presentase yang menjawab (c) $p=\frac{22}{35} \times 100 \%=62,86 \%$, hasil presentase yang menjawab (b) $p=$ $\frac{2}{35} \times 100 \%=5,71 \%$, sedangkan yang menjawab (a) adalah $0 \%$.

Berdasarkan hasil dari angket tentang dampak pola hidup terhadap kebugaran jasmani pada item pertanyaan no 14 responden yang mejawab (e) ke rumah sakit $=15$ siswa, yang menjawab (d) puskesmas = 15 siswa, yang menjawab (c) meminum obat tradisional adalah tidak ada, sedangkan yang menjawab 
(b) cukup pengobatan alternatif $=5$ siswa, dan yang menjawab (a) pergi ke dukun adalah tidak ada. (didapat dari hasil penjumlahan jawaban $a, b, c, d$, dan e) maka hasil presentase yang menjawab (e) adalah $p=$ $\frac{15}{35} \times 100 \%=42,86 \% \quad$ hasil presentase yang menjawab (d) adalah $p=\frac{15}{35} \times 100 \%=42,86 \%$, hasil presentase yang menjawab (c) adalah $0 \%$, hasil presentase yang menjawab $\quad$ (b) $p=\frac{5}{35} \times 100 \%=$ $14,28 \%$, sedangkan yang menjawab (a) adalah $0 \%$.

Berdasarkan hasil dari angket tentang dampak pola hidup terhadap kebugaran jasmani pada item pertanyaan no 15 responden yang mejawab (e) selalu adalah tidak ada, yang menjawab (d) sering adalah tidak ada, yang menjawab (c) jarang sekali = 30 siswa, sedangkan yang menjawab (b) tidak pernah = 5 siswa, dan yang menjawab (a) sangat tidak pernah adalah tidak ada. (didapat dari hasil penjumlahan jawaban $a, b, c, d$, dan e) maka hasil presentase yang menjawab (e) adalah $0 \%$ hasil presentase yang menjawab (d) adalah $0 \%$ hasil presentase yang menjawab $\quad$ (c) $\quad p=\frac{30}{35} \times 100 \%=$ $85,71 \%$, hasil presentase yang menjawab $\quad$ (b) $\quad p=\frac{5}{35} \times 100 \%=$ $14,29 \%$, sedangkan yang menjawab (a) adalah $0 \%$.

Tabel 1.

\begin{tabular}{c|c|c|c}
$\begin{array}{c}\text { Norma } \\
\text { penelitian }\end{array}$ & $\begin{array}{c}\text { Frekuensi } \\
\text { absolut }\end{array}$ & $\begin{array}{c}\text { Frekuensi } \\
\text { relative } \\
\%\end{array}$ & kategori \\
\hline$\geq 15.31$ & 2 & $9,09 \%$ & SK
\end{tabular}

\begin{tabular}{c|c|c|c}
$\begin{array}{c}12.11- \\
15.30\end{array}$ & 7 & $31,81 \%$ & $\mathrm{~K}$ \\
\hline $\begin{array}{c}10.49- \\
12.10\end{array}$ & 10 & $45,51 \%$ & $\mathrm{~S}$ \\
\hline $\begin{array}{c}09.41- \\
10.48\end{array}$ & 2 & $9,09 \%$ & $\mathrm{~B}$ \\
\hline $\begin{array}{c}08.37- \\
09.40\end{array}$ & 1 & $4,50 \%$ & $\mathrm{BS}$ \\
\hline$\leq 8.37$ & - & - & -
\end{tabular}

dapat disimpulkan bahwa dari 22 siswa laki-laki, sebanyak 2 siswa (9,09\%) masuk kategori waktu yang ditempuh $\geq$ 15,31 , sebanyak 7 siswa $(31,81 \%)$ masuk kategori waktu yang ditempuh 12.11 15.30, sebanyak 10 sisw (45,51\%) masuk kategori waktu yang ditempuh 10,49 12.10, sebanyak 2 siswa $(9,09 \%)$ masuk kategori yang ditempuh 09.41 - 10.48, sebanyak 1 siswa (4,50\%) masuk kategori waktu yang ditempuh 08.37-0940.

Tabel 2.

\begin{tabular}{c|c|c|c}
$\begin{array}{c}\text { Norma } \\
\text { penelitian }\end{array}$ & $\begin{array}{c}\text { Frekuensi } \\
\text { absolut }\end{array}$ & $\begin{array}{c}\text { Frekuensi } \\
\text { relative } \\
\%\end{array}$ & kategori \\
\hline$\geq 18.31$ & - & - & SK \\
\hline $\begin{array}{c}16.55- \\
18.30\end{array}$ & 3 & $23,07 \%$ & $\mathrm{~K}$ \\
\hline $\begin{array}{c}14.31- \\
16.54\end{array}$ & 8 & $61,54 \%$ & $\mathrm{~S}$ \\
\hline $\begin{array}{c}12.30- \\
14.30\end{array}$ & 2 & $15,39 \%$ & $\mathrm{~B}$ \\
\hline $\begin{array}{c}11.50- \\
12.29\end{array}$ & - & - & $\mathrm{BS}$ \\
\hline$\leq 11.50$ & - & - & $\mathrm{BS}$
\end{tabular}

bahwa dari 13 siswi perempuan, sebanyak 3 siswi (22,07\%) masuk kategori waktu yang ditempuh 16.5518.30 , sebanyak 8 siswi $(61,54 \%)$ masuk kategori waktu yang ditempuh $14.3116,54$, sebanyak 2 siswi $(15,39 \%)$ masuk kategori waktu yang ditempuh 12.30-14.30. 


\section{Pembahasan}

Berdasarkan pada deskripsi data dan olahan data mengenai "Analisis Dampak Pola Hidup Terhadap Kebugaran Jasmani (Studi Kasus Pada Siswa Siswi Kelas XI IPS 1 SMA Negeri 8 Kota Bengkulu)", maka dapat dikemukakan jawaban dari rumusan masalah yang telah diajukan sebelumnya yaitu "Bagaimanakah dampak pola hidup terhadap kebugaran jasmani pada siswa-siswi kelas XI IPS 1 SMA Negeri 8 Kota Bengkulu?" yang berkenaan dengan dampak pola hidup. Untuk lebih jelasnya jawaban dari pertanyaan dapat diuraikan sebagai berikut :

Menurut Lisnawati (2001:75) pola hidup adalah menggambarkan pola perilaku sehari-hari yang mengarah pada upaya memelihara kondisi fisik, mental, dan sosial berada dalam keadaan positif. Dari jawaban responden yang di kemukakan bahwa pada item petanyaan no 1 lebih banyak menjawab (e) rajin berolahraga pagi hari dengan presentase 42,86\%, jawaban responden pada item pertanyaan no 2 lebih banyak menjawab (e) selalu dengan presentase $57,14 \%$, jawaban responden pada item no 3 lebih banyak menjawab (e) selalu dengan presentase 68,57\%, jawaban responden pada item pertanyaan no 4 lebih banyak menjawab (c) kadangkadang dengan presentase 42,86\%, jawaban responden pada item no 5 lebih banyak menjawab (d) sering dengan presentase $57,14 \%$, jawaban responden pada item pertanyaan no 6 lebih banyak menjawab (d) sering dengan presentse 42,86\%, jawaban responden pada item petanyaan no 7 lebih banyak menjawab (c) 4-5 jam sehari dengan presentase $42,86 \%$, jawaban responden pada item petanyaan no 8 lebih banyak menjawab (b) sering dengan presentase 57,14, jawaban responden pada item pertanyaan no 9 lebih banyak menjawab (a) selalu dengan presentase 57,14 , jawaban responden pada item petanyaan no 10 lebih banyak menjawab (e) sangat berpengaruh dengan presentase 57,14, jawaban responden pada item pertanyaan no 11 lebih banyak menjawab (e) kekuatan otot, kelenturan, daya tahan dan kelincahan dengan presentase 57,14, jawaban responden pada item pertanyaan no 12 lebih banyak menjawab (c) jarang sekali dengan presentase 57,14, jawaban responden pada item pertanyaan no 13 lebih banyak menjawab (c) hanya sedikit dengan presentase 62,86\%, jawaban responden pada item pertanyaan no 14 lebih banyak menjawab (e) ke rumah sakit dan (d) puskesmas dengan presentase $42,86 \%$, jawaban responden pada item pertanyaan no 15 lebih banyak menjawab (c) jarang sekali dengan presentase $85,71 \%$.

Menurut Engkos Kosasih (1985:10) mendefinisikan kebugaran jasmani sebagai suatu keadaan seseorang yang mempunyai kekuatan (strength), kemampuan (ability), kesanggupan, dan daya tahan untuk melakukan pekerjaannya dengan efisien tanpa kelelahan.Berdasarkan hasil data diproleh dari jumlah sampel 35 orang dibagi menjadi 2 keriteria yaitu 22 lakilaki dan 13 perempuan ternyata ratarata kecakapan dalam dampak pola hidup terhadap kebugaran jasmani pada 
siswa dan siswi kelas XI IPS 1 SMA Negeri 8 Kota Bengkulu di kategorikan berada pada kategori sangat kurang dengan persentase $9,09 \%$ sebanyak 2 orang untuk siswa laki-laki, sedangkan pada kategori kurang terdapat 7 orang siswa laki-laki 3 orang siswi perempuan dengan persentase $31,81 \%$ dan $23,07 \%$, selanjutnya pada kategori sedang terdapat 10 orang siswa laki-laki dan 8 orang siswi perempuan dengan persentase $45,51 \%$ dan 61,54\%, sedangkan pada kategori baik terdapat 2 orang siswa laki-laki dan 2 orang siswi perempuan dengan persentase 9,09\% dan $15,39 \%$, sedangkan pada kategori baik sekali hanya pada siswa laki-laki terdapat 1 orang dengan persentase $1,50 \%$. Berdasarkan hasil data yang diperoleh dari jumlah sampel 35 orang dibagi menjadi 2 kategori kriteria yaitu 22 laki-laki dan 13 perempuan, ternyata dari pengelompokan 2 kriteria tersebut di dapat rata-rata waktu yang ditempuh pada tes aerobic lari 2400 meter siswa laki-laki yaitu 12,29 menit sehingga dapat dikategorikan kurang, sedangkan di dapat rata-rata waktu yang di tempuh pada tes aerobic lari 2400 meter siswi perempun yitu 16,38 menit sehingga dapat dikategorikan sedang. Maka dapat disimpulkan bahwa ratarata dari kecakapan dalam dampak pola hidup terhadap kebugaran jasmani pada siswa dan siswi kelas XI IPS 1 SMA Negeri 8 Kota Bengkulu untuk siswa laki-laki masuk kategori kurang dan perempuan masuk kategori sedang.

\section{PENUTUP}

\section{Simpulan}

Dari hasil angket dilihat dari lingkungan keluarga, lingkungan sekolah, lingkungan masyarakat, pengetahuan, pemanfaatan dan perilaku sehari-hari diperoleh hasil yang baik, sedangkan dari hasil tes lari $2.400 \mathrm{~m}$ diperoleh hasil untuk siswa laki-laki waktu yang ditempuh 12.29 menit dilihat dari table frekuensi masuk dalam kategori kurang, sedangkan pada siswi perempuan waktu yang ditempuh 16.38 menit dilihat dari table frekuensi dengan kategori sedang. Pada siswa lakilaki memiliki kebugaran jasmani yang kurang dikarenakan masih kurangnya penerapan pola hidup dalam kegiatan sehari-hari, sedangkan pada siswi perempuan memiliki kebugaran jasmani yang sedang karena mereka sudah mulai menerapkan pola hidup yang baik dalam kehidupan sehari-hari.

\section{Saran}

Setelah melakukan penelitian "Analisis Dampak Pola Hidup Terhadap Kebugaran Jasmani (Studi Kasus Pada Siswa Siswi Kelas XI IPS 1 SMA Negeri 8 Kota Bengkulu", maka penulis memberikan saran-saran sebagai berikut:

1. Perlunya pemahaman lebih banyak tentang pola hidup sehat terhadap kebugaran jasmani untuk siswa dan siswi kelas XI IPS 1 di SMA Negeri 8 Kota Bengkulu agar dapat diterapkan diberbagai aspek kehidupan keluarga, sekolah, dan masyarakat

2. Pola hidup sehat untuk siswa dan siswi kelas XI IPS 1 SMA Negeri 8 Kota Bengkulu perlu diperhatikan seperti keadaan tidak tidur sampai larut malam, memelihara kebersihan badan dengan baik, pola makan yang benar, olahraga yang rutin agar mendukung untuk mendapatkan kebugaran jasmani.

\section{DAFTAR PUSTAKA}


Asril. (2009). Evaluasi Pendidikan Jasmani dan Olahraga. Malang: Wineka Media

Cd.Dirman, \& Juarsih Cicih. (2014). Krakteristik Peserta Didik. Jakarta: PT Rineka Cipta

Kosasih, Engkos. (1985). http://pengertiankebugaranjasmani.blogs pot.co.id/1985/10/pengertiankebugaran. html

Heru, Setjyaka. (2016). Hidup Sehat, Kinerja

Melesat. Yogyakarta: Sarfa

Lisnawati. (2001). http://pengertianparaahli.blogspot.co.id/ 2001/06/pengertian-gaya-hiduplifestyle.html

Mahmud. (2011). Metode Penelitian Pendidikan. Bandung: CV Pustaka Setia

Sarwoto, \& Soetedjo, Bambang. (1933). Materi Pokok Pendidikan Kesehatan dan P3P. Jakarta: Universitas Terbuka, Depdikbud

Sugiyono. (2014). Metode Penelitian Kombinasi (Mixed Methods). Bandung: Alfabeta

Suharto, dkk. (2003). Pola Hidup Sehat dan Segar. Jakarta: Pusat Pengembangan Kualitas Jasmani

Widanggar, dkk. (2002). Ketahuilah Tingkat Kesegaran Jasmani Anda. Jakarta: Pusat Pengembangan Kualitas Jasmani. 